\title{
Dazzled by New Media: Mbembe, Tonda, and the Mystic Virtual
}

\author{
Peter Geschiere
}

\begin{abstract}
Inspired by Mbembe's emphasis on plasticity as a hallmark of African forms of knowledge, Geschiere notes the risk that this leads to a celebration of Africanness, sliding into culturalism and identity politics. But Mbembe relates this plasticity also to the continent's position as the last frontier of capitalism. Such a historical view converges with Joseph Tonda's work on éblouissement (endazzlement) as a global phenomenon. Everywhere people are now being blinded by an overproduction of images. However, Africans have a long experience of living with multiple realities and "alternative facts." Is this relevant for dealing with the risk that we all become blinded by the images we ourselves have created?
\end{abstract}

Résumé: Inspiré par l'accent mis par Mbembe sur la plasticité comme marque des formes africaines de connaissance, Geschiere note le risque que cela entraîne une célébration de l'africanité, glissant dans le culturalisme et la politique identitaire. Mais Mbembe met aussi en relation cette plasticité avec la position du continent comme dernière frontière du capitalisme. Une telle vision historique converge avec le travail de Joseph Tonda sur l'éblouissement (dazzlement) comme phénomène global. Partout, les individus sont aujourd'hui aveuglés par une surproduction

African Studies Review, Volume 64, Number 1 (March 2021), pp. 71-85

Peter Geschiere is emeritus professor for the Anthropology of Africa at the University of Amsterdam and Leiden University and co-editor of Ethnography (Sage). His publications include The Modernity of Witchcraft (Univ. Of Virginia Press, 1997), Perils of Belonging: Autochthony, Citizenship and Exclusion in Africa and Europe (Univ. of Chicago Press, 2009), and Witchcraft, Intimacy and Trust: Africa in Comparison (Univ. of Chicago Press, 2013). E-mail: P.L.Geschiere@uva.nl

(C) The Author(s), 2021. Published by Cambridge University Press on behalf of the African Studies Association. This is an Open Access article, distributed under the terms of the Creative Commons Attribution-NonCommercial-ShareAlike licence (http://creativecommons.org/licenses/by-nc-sa/4.0/), which permits noncommercial re-use, distribution, and reproduction in any medium, provided the same Creative Commons licence is included and the original work is properly cited. The written permission of Cambridge University Press must be obtained for commercial re-use.

doi:10.1017/asr.2020.80 
d'images. Cependant, les Africains ont une longue expérience de vivre la avec des réalités multiples et des "faits alternatifs. » Ces réaslités sont-ellesils pertinentes pour faire face au risque que nous devenions tous aveuglés par les images que nous avons nous-mêmes créées?

Resumo: Tomando como ponto de partida a ênfase atribuída por Achille Mbembe à plasticidade como imagem de marca das formas africanas de conhecimento, Geschiere aponta o risco de que isso conduza à celebração da africanidade, degenerando no culturalismo e na política identitária. Mas Mbembe também relaciona esta plasticidade com o posicionamento do continente enquanto última fronteira do capitalismo. Uma tal visão historiográfica coincide com o trabalho de Joseph Tonda acerca do éblouissement (deslumbramento) enquanto fenómeno global. Por todo lado, o ser humano está hoje ofuscado pela sobreprodução de imagens. Os africanos, porém, têm uma longa experiência de vida com múltiplas realidades e "factos alternativos". Serão estas questões relevantes para lidarmos com o risco de todos ficarmos ofuscados pelas imagens que nós próprios criámos?

Keywords: African forms of knowledge; culturalism; witchcraft; nganga (healer); social media; alternative facts; éblouissement (dazzlement)

(Received 28 June 2019 - Revised 29 June 2020 - Accepted 16 July 2020)

One of the topics I find challenging in Achille Mbembe's rich Abiola lecture, "Future Knowledges," is his determined effort to think through the notion of "decolonizing" in relation to changing parameters of knowledge (see also Newell \& Pype's introduction to this forum). For Mbembe, the "computational age" brings increasing uncertainty on "what actually counts as knowledge."

Knowledge has always been tied to the requisite of 'empirical validation.' Knowledge is that which has to be validated empirically; that which has undergone a methodical, systematic process of empirical validation. No knowledge is free from these constraints. Whatever is free from it represents at best wisdom, but not knowledge as such. (2016b:20)

But new media effect deep changes in this respect.

Life behind the screens is fast becoming a fact of daily existence. People are exposed to, are producing and absorbing more images than they ever had. (2016b:24)

In another text, published at the very end of 2016-so, shortly after he presented his Abiola lecture-Mbembe used even stronger formulations to capture what is at stake. There he powerfully summarized the impact of the new media forms as breaking "the tabs on the unconscious:" 


\begin{abstract}
New media forms have not only lifted the lid previous cultural eras had put on the unconscious. They have become the new infrastructures of the unconscious. Yesterday, human sociality consisted of keeping tabs on the unconscious. For the social to thrive it meant exercising vigilance on ourselves, or delegating to special authorities the right to exercise such vigilance... [This] was to set the conditions for sublimation. Not all desires could be fulfilled... the capacity to limit oneself was the essence of one's freedom and the freedom of all... [Now] The unconscious can roam free. Sublimation is no longer necessary. (Mbembe 2016a)
\end{abstract}

These are visionary statements, food for thought. In my comment I want to focus on two different strands that are suggested by Mbembe's reflections on the impact of changing parameters of knowledge. One is the suggestion that this changing situation offers new chances for validating alternative forms of knowledge than those that have acquired hegemonic status in academia and in the modern world at large, notably, new chances for "African" forms of knowledge. My question-inspired also by some elements in Mbembe's oral presentation and in the discussions during the panel (at the ASA conference, Chicago 2016) on which this ASR forum is based-is whether this interest in an African specificity does not risk bringing a return of culturalism. Isn't there a danger in freezing such an African specificity as an ahistorical "given," viewing "culture" as some sort of black box?

Mbembe's lecture also suggests other lines of thought. At the very end of his lecture, he connected this idea of an African particularity to the continent's special position in the present-day world as the "last frontier of capitalism" ("the last territory on Earth that has not yet been entirely subjected to the rule of capital" [2016b:29]). In such an approach, special traits of African knowledge are related to the continent's historical position in the world. And such a historical context is indeed crucial if we want to explore further the idea of African ways of knowing having special relevance to understanding the changing parameters of knowledge globally. On this point - and this is the second strand I want to focus on-Mbembe's approach relates to the equally visionary insights of the Libreville sociologist Joseph Tonda, especially to the latter's recent use of the notion of Éblouissements (Dazzlements). For Tonda, not only Africa but the whole world is becoming ever more dazzled-"colonized" is the word Tonda uses, to emphasize that people are subjected to the images that they themselves create-by a vortex of pictures (Tonda 2015). ${ }^{1}$ But his vivid examples from everyday life in Libreville and also from Brazzaville (where he grew up) of images "that kill the eyes," as people there say, suggest that in these settings this is nothing new. Most striking are his examples of images that are now reproduced and aggrandized by the new media: healers who combine local plants with pictures from western journals to conjure up powerful collages, TV shots of occult rituals that convey hidden powers in new ways. Yet, living with such a vortex of hidden meanings and the constant struggle to decide what is "fake" and what is "real" is nothing new to many Africans, for whom any attempt to 
separate the visible from the invisible, or the real from the false, has always been highly precarious. One question in this respect is whether such longstanding African experience might have special relevance for the present-day global struggle to retain control over the vortex of images produced on an ever-dazzling scale by the new media.

\section{Culturalism and Its Dangers}

Mbembe explicitly links the new parameters of knowledge introduced by the internet to older African experiences. In his lecture he emphasized that “...it is as if the Internet was speaking unmediated to this archaic unconscious or to these societies' deepest and hidden brain" (2016b:26), and he referred to Jane Guyer's pioneering explorations of "precolonial African ways of knowing" as not "specialist" - "not controlled and monopolized by a small cadre of experts or a secret society hierarchy" (Mbembe 2016b:25; Belinga \& Guyer 1995). Mbembe elaborated on this idea by celebrating "African plasticity" as a hallmark of precolonial cultures and forms of knowledge:

(T) he plasticity of digital forms speaks powerfully to the plasticity of African precolonial cultures and to ancient ways of working with representation and mediation, of folding reality.....Things and objects, the animal and organic worlds were also repository of energy, vitality and virtuality and as such they constantly invited wonder and enchantment. Tools, technical objects and artifacts ... served as the linchpin to transgress existing boundaries so as to access the Universe's infinite horizons. (Mbembe 2016b:24; see also Newell \& Pype's intro to this forum)

The emphasis on plasticity and openness seems to sit uneasily with some versions of the recent call for a decolonization of knowledge, those that are structured around a radical separation of African and outside (notably Western) forms of knowledge. As Mbembe continues:

\footnotetext{
Whatever its origins, knowledge was something to be captured if necessary from outside as long as it could be mobilized for action or for performance.... Indeed in old African traditions, human beings were never satisfied of simply being human beings. They were constantly in search of a supplement to their humanhood. (2016b:26) ${ }^{2}$
}

This strong and eloquent argument seems to run counter to dramatic events in, for instance, South Africa during the preceding year marked by students' threats to burn university libraries ${ }^{3}$ as repositories of "Western knowledge," for which there would no longer be a place with the urgent need for decolonizing. ${ }^{4}$

Yet, I cannot help wondering whether the heavy emphasis on these alternative forms of knowledge as being "African," even if plasticity is seen as the hallmark, is not risky. Mbembe's and Guyer's examples evoke indeed a different way of building up knowledge, more open and less hierarchical. 
In her pioneering articles (Guyer 1993, 1996), Guyer relates this to a tendency toward "multiple self-realization," allowing for the "composition" of different forms of knowledge and opportunities in order to achieve success. But one can wonder whether, on the one hand, these forms of knowledge are special to Africa and, on the other, whether they are relevant to the continent as a whole. One can, indeed, cite many examples from all over the world of similar open and hybrid forms of knowledge that do not fit with established forms of hierarchy. In Melanesia, for instance, the older complex of cargo cults-which believe that the ancestors bring an abundance of western goods to their descendants - continue to take on ever new forms. Andrew Lattas's spokespersons refer now to hidden highways and huge ships, the ancestors being supposed to live in Japan waiting for their children (Lattas 2010; see also Rio et al. 2017). In Mongolia, the return of shamanism, supposed to be almost extinct after destructive socialist and neoliberal intermezzos, is characterized by similar hybrid forms of knowledge (see Buyandelger 2013; Pedersen 2011). In Amazonia, Eduardo Viveiros de Castro (2009) discovers a "native perspective," dominated by a "predatory metaphysic and the eye of the jaguar" that is in every respect the opposite of forms of knowledge that dominate in (Western) academia. One can even say that such alternative forms of knowledge remain present as strong undercurrents in supposedly scientific Western societies (think of the continuing interest in "witchcraft" and the ebullience of New Age movements in the West).

More important might be to relativize Mbembe's and Guyer's view of alternative forms of knowledge-inspiring as they are-as applying to "African" societies in general. Elsewhere (Geschiere 2007), in a comment on Guyer's seminal 2004 book Marginal Gains (to which Mbembe contributed as well), I noted that her emphasis on "multiple self-realization" works as a real eye-opener for the societies from the forests of West Central Africa, from which she takes her main examples in the early articles on the subject. In these "big-man" societies, the influx of new opportunities in the nineteenth century created by the impact of European trade allowed for the "composition" of new packages of knowledge-combining local forms of prestige with success through new opportunities - that shaped new ways of validating social pre-eminence. Typically, commodification was in these societies a rapid and all-pervasive process, with money-allowing for new ways of "selfrealization"-penetrating very quickly into the exchange of prestige-goods that formed the core of the local order. However, such insights are less helpful for understanding developments in the chiefly societies a few hundred miles to the west and north of the forest area, for which one can certainly not deny that local ways of knowing were in fact monopolized by a small elite of experts imposing a rigid hierarchy. For instance, for the Bamileke chieftaincies in western Cameroon, strictly controlled secret knowledge is still essential to the striking resilience of the chiefs and the (in some respects) suffocating hierarchy built around their courts (see Warnier 2007).

Such a plea for relativizing the general validity of our vision of "African" forms of knowledge as determined by plasticity and multiple self-realization is 
not just an example of the Bongo-Bongoism that Mary Douglas (1970/1996: $\mathrm{xxxv}$ ) attributed to most anthropologists (referring to a tendency to come up with another obscure group for undermining ambitious general propositions). In anthropology, we have seen many examples of how culturalismtaking culture as a self-evident given, outside of history-can turn around well-intentioned visions, giving them unintended implications, such as fostering dangerous forms of identity politics. I do think it is worthwhile to note that, on the one hand, there were many African societies-in precolonial times as well-with a less open approach to questions about the kinds of knowledge that were permitted or that had to be banned, and where strong hierarchies and secret societies did strive for closure and control over what people should know and not know. And on the other hand, that views of objects as charged with power, whether dangerous or healing, and celebrations of constantly innovating forms of cognition to expand people's horizons were (and are) present in many parts of the world. Yet it is true that almost everywhere these older forms of knowledge have become subjected to the increasingly heavy grid of modern thought with its striving for clarity and unequivocalness.

\section{Living with dazzling images, African Experiences}

As he states in other passages of his seminal Abiola lecture, Mbembe relates African plasticity also to its special position as "the last territory on Earth that has not yet been entirely subjected to the rule of capital." Following this perspective, it is easier to do justice to parallels to other peripheral areas (both globally and inside formations that are dominated by capital). It relates as well to his idea, also quoted above, that new media forms have a liberating effect on the conscious, allowing it "to roam free." ${ }^{5}$ It is especially on this point that a comparison with Joseph Tonda's work can be enlightening.

A central theme in Tonda's work-based on his deep involvement with everyday life in Brazzaville and Libreville, but also on a highly creative use of sociology and anthropology's classics - is how new media, first TV and now a whole plethora of social media, give new reality to the invisible, making it visible in all sorts of ways and thus affirming its omnipresence. The image no longer represents the real; rather, it is the real. Thus, when the Gabonese President puts his initiation as Grand Master of the national Freemason lodge on YouTube, mixing it with images from his involvement with local secret cults, these images impress his mystic invulnerability on people's minds as "the" reality. What is new in Tonda's 2015 book is that he relates now much more to images circulating on a global scale. The obsessive images of pop-star Nicki Minaj and all the things she does with her black body-playing with race and eroticism-repeat the kind of éblouissement that is familiar from everyday life in African cities, but now on a global scale. Tonda's last book is again very, very rich. So it allows for all sorts of readings, and mine might be a special one (though he more or less acknowledged it by asking me to write an Afterword for the book). For me, Tonda's analysis of such éblouissement opens up 
interesting parallels to Mbembe's global vision of new parameters for what is now considered to be "knowledge." Tonda's book shows that, in a setting such as present-day Libreville, people's everyday playing with the imaginary-playing that has a certain ludic allure but can quickly become deadly serious-is not a sign of Gabon's (or Africa's) otherness, but has instead become prophetic for the whole world.

In a time when people in the West also have to learn and live with "alternative facts" and "fake news," as Instagram and Facebook take over for many the authority of what is news and what is not, basic standards of what counts as "knowledge" and what does not have become highly wobbly. Organized hacking, backed up by states (in the West as much as in other parts of the world), or Photoshopping as a common political tactic, do not discourage people from resorting to the internet as a source of truth. What may be different now is that in the West many people are still shocked about the ways that the internet-and notably the new social media-unsettle certainties about knowledge and about real versus fake by the cascade of images they produce and proliferate. In contrast, Tonda's vivid examples highlight that for African societies such turmoil and confusion is hardly new. The sensation of being surrounded by a living environment is a common experience in Africa; just as common is the constant preoccupation with the invisible that can at any time penetrate the visible world (see also Geschiere 2017). Hence the impossibility of separating different parameters of perception. All this makes it a truism in many African contexts that different levels of reality are constantly impinging upon each other. It is a reality one must somehow learn to live with. Can we see Africa in this respect as a forerunner of the West? ${ }^{6}$ An obvious question becomes, then, to what extent African ways of doing can also suggest ways for dealing with such confusion that seems to haunt the West now. But first, in order to provide some concrete basis for my discussion, a few quick remarks on an issue that crops up in many parts of present-day Africa: people's sometimes desperate attempts to deal with a supposed proliferation of new forms of "witchcraft." This is a field in which people's struggles to learn and live with different realities come particularly to the fore. It is also a domain where the impact of new technology has brought dramatic changes. ${ }^{7}$

\section{Witchcraft, reality, and new technology}

Elsewhere I have characterized witchcraft as an "overproduction of meaning" (Geschiere 1999). Especially during the beginning of my research among the Maka in East Cameroun, where I have worked since 1971, I had a feeling that once I had shown interest in the world of the djambe (the term they now translate as sorcellerie), I had opened a hidden maelstrom of rumors, gossip, and "explanations." There seemed to be no end to the sizzling magma (to use an image dear to Joseph Tonda) oozing out. I borrowed the idea of an “overproduction of meaning" from Robert Weller's fascinating study (1994) of spirit cults in Taiwan. For him, the "indeterminate meaning" of these cults 
is a strength-they can address almost anything, and this is why they keep coming up in a dazzling richness of form. However, it is at the same time a weakness, since it seems to make them incapable of developing a counterhegemonic project-to go, in Weller's terms, through a phase of "precipitation" of the kind of "interpretative unification" that could lead to a breakthrough of the status quo. It is this overproduction of indeterminate meaning that relates so directly to issues touched upon by Mbembe and Tonda, and to the confusion about alternative facts and virtual realities that seems to mark our times, in the West as much as in Africa.

My access to the baroque cascade of djambe's "indeterminate meaning" was therefore by words. No doubt this is a general trait; words are vital, for the working people attribute to them occult powers. Think of the title of Jeanne Favret Saada's by now classical study of witchcraft in Normandy in the 1970s: Les mots, la mort et les sorts (1977), rightly translated as Deadly Words. However, I soon came to learn that witchcraft is at least as much about seeing as about speaking. In many parts of Africa, the hallmark of becoming initiated is to acquire "a second pair of eyes," an extra visionary capacity that enables the witch (or the healer) to see things others cannot see. In many respects, the expertise of the healer-for the nganga in Bantu-speaking Africa as much as for their colleagues in other parts of the continent or even the world-is to be able to evoke a vision, a collage of images, that fits and thus convinces and liberates the patient. Seeing is vital in Michael Taussig's dazzling ethnography of the Amazonian healer Don Santiago and his "theatre of yagé nights," conjuring up pintas_images-through powerful "montages" that were often extremely frightening and therefore could have healing as well as liberating effects (Taussig 1987:441-44).

Seeing and the evocation of disturbing images was equally central to the art of Ms. Menduga, my friend from a neighboring village who, at the beginning of my research, was considered the greatest nganga of the district. As proof of this, my friends invariably mentioned that there were regularly big black Mercedes cars parked in front of her humble house-which meant that an important politician had come to ask for support and advice. She was a regular visitor in our modest house (even though I had chosen to live in a mud house, I was still a ntangue, white man, and therefore of special interest). She also liked to mock me. "Why did I ask so many questions about the djambe? Did I want her to give me the second pair of eyes? Then I could see for myself what the witches were doing." But when, a few days later, I accepted, she withdrew the offer hastily: "No it was too tricky. If I could see the witches, they could see me and attack. And if I got hurt, she would be in trouble with the D.O." After this, people agreed that I was "innocent" (which is not a compliment; it verges on silly). Words-talking about the djambe-can only do so much. Seeing was and is the vital step.

However, Menduga kept regaling me with evocative stories that clearly centered on conjuring up convincing images to confirm her special powers. Her favorite story was about her own initiation by her "professor" (a vague person about whom we only came to know that he lived far away, much 
deeper in the forest). She told me that she went to search for midu (charged objects) with a great nganga "because of her anger." Her son was in the army and was driven crazy by his own brothers (that is, boys from the same village). She had "seen" everything (implying that she knew already how to use the djambe in her belly), but she could not do anything. This is why she went to look for a nganga who had the reputation of being really powerful.

When she finally arrived at his place, this nganga asked her, "why did you come?" (even though he knew of course very well why she had come to him). She explained everything, and he made a mixture of cocoyam, pepper, and salt together with his own saliva. She swallowed it all. In this manner, he gave her his djambe. His saliva was so strong that, without the cocoyam and salt, she could have never gotten the medicine down. Then he put her in contact with the mindjim (the spirits of the dead and the witches). One night he told her to lie down. He tapped for a long time on her back and then had her swallow some more medicine. Her body remained recumbent as if she were dead, but her soul (shishim) flew away toward the mindjim (this is just what the witches do, leave their bodies at night and fly away to meet other witches). Menduga always became enthusiastic when she spoke of her encounters with the mindjim; it was a fabulous world. She reported that they are pale like the white people, and they live underground, in vast and rich palaces. They dance the "tango" (she seems to have thought here of modern Cameroonian dancing), but they dance much better than anyone here. Her nganga had told her to find her mother there, but, to her surprise, she found that in the world of the mindjim your relatives run away from you. ${ }^{8}$ Finally she was able to catch her mother, who gave her a lot of medicine (biang, a word of the neighboring Ewondo). On her way back, she managed also to get hold of her sister, who had just been killed by her husband. She gave Menduga some medicine against jaundice. This is why she had been able to heal so many people of jaundice.

Even more evocative was her story about how her professor had given her a "mirror" - a tool that turned out to play a crucial role in her practice. The next night her professor caused her again to sink into a deep, deep sleep. But before this, he showed her a narrow bottle and some small sticks. When she woke up again, he showed her that the sticks were now inside the bottle in a greyish sticky fluid. He taught her also how to use this "mirror." When she received a new client, her very first question was: "Did you go out (ouas) yourself?"-meaning whether the client had joined the witches in their nightly escapades. Then she would look into her "mirror"-that is, make the liquid pass between the sticks inside. If it passed cleanly, the client "had not gone out"; if a drop remained hanging, the client had lied. If clients would immediately confess their nocturnal escapades, they could still be treated. But if they continued to lie, Menduga could not help them anymore. Which meant that they would become easy prey for witches in pursuit.

It is clear that Menduga's vivid stories were full of uncertainties and even inconsistencies. One of my assistants, for instance, insisted that she had left out a crucial moment from the story of her initiation. Everybody knew that, at 
the very moment of the initiation, when receiving the famous "second pair of eyes," the candidate nganga had to offer a precious gift to the professoraccording to many, the gift was so precious that it mostly consisted of a close relative to be delivered into the powers of the professor. ${ }^{9}$ But such omissions - and there were many more aspects that were debated with heatdid not make my companions doubt her story. Despite all the inconsistencies and shifts—strongly reminiscent of Weller's "indeterminate meaning" —or maybe rather because of such uncertainties, djambe (witchcraft) was (and is) an all-pervasive reality. Behind the daylight world there is a shadow world complementing what one can see by day with a cascade of alternative images that until recently remained mostly invisible.

There is, indeed, good reason to emphasize this "until recently," because especially since the turn of the century, new social media has brought big changes in this respect. The spread of TV and film during earlier decades had already contributed to making things visible that were long supposed to remain invisible. But the subsequent spread of video cameras and cell phones brought a real breakthrough. The new Ghanaian and Nigerian movies put witchcraft on the screen with shocking intensity and directness in many parts of West and Central Africa. The video camera offered new possibilities for making low budget films, and it is striking that the new and enthusiastic filmmakers focused notably on "witchcraft" - which is still the main topic of what has come to be known as "Nollywood" (Larkin 2008). Clearly these are the things audiences finally wanted to see! Most video films have a familiar plot, strongly marked by Pentecostal fervor in its crusades against witchcraft as the manifestation of the devil. A pious Christian has to go through a long period of misery; the cause will only gradually emerge in the figure of a witch, often from the protagonist's village of birth or from within the family. For some time, the devil in the figure of the witch seems to prevail, but finally she (only rarely "he") is vanquished by a Pentecostal pastor. In her last book, Birgit Meyer (2015) graphically illustrates how important the new technology of "special effects" was for these filmmakers. Suddenly the weird transformations of the witch could be shown through vivid images: the evil person gradually turning into a snake, a crocodile, a vulture, a panther, or even the devil himself. Even more gruesome is the horrible destruction of the witch, her/his body shown on fire or just crumbling as a well-deserved punishment.

How did all this affect people's imaginaries? What used to be hidden and mostly invisible is suddenly there, starkly visible on the screen. One effect is clearly further "overproduction." The Pentecostal movies vie in making the full horrors of witchcraft visible through ever more baroque images. One might suppose that such inflation leads to saturation among the public, but so far there is no sign of this. Yet there is also another effect. Witchcraft on the screen becomes fixed, acquiring a new reality. In everyday life, the collages evoked by the nganga are always precarious. They can be contested and debunked-as happened to my friend Menduga when I returned in 1973; people said she had "lost" her power and had been bound by the witches 
herself. Witchcraft in everyday life is always uncertain and full of sudden shifts. But on the screen, it seems to be unequivocally clear.

The first time I was directly exposed to witchcraft on the screen in an African setting was at Eric de Rosny's conference on Justice et Sorcellerie (Yaounde 2005). A friend showed a brief and quite clumsy movie about a girl denouncing her elders for involving her in a witch coven (which is a not unusual scene in the village). When I showed a copy later to Mbembe, he said the whole thing was fake and arranged. But the filmmaker insisted that he had happened to pass by (the scene took place in a village along the main road between Douala and Yaounde) and that it had been a real event. If it was actually fake, one can only conclude that the girl was a gifted actress-her wild denunciations, adding ever more gruesome details about how they boarded up their nightly place, tied their victims, cut them up with pieces of bamboo, and so on, seemed to reflect clear hysteria and enjoyment of the situation. However, this was my impression. It came as a shock to me that the whole audience-mostly students of the Catholic University of Central Africa, a most respectable institute-stood as one man/woman in support of the girl.

Why was I shocked? Not so much because I thought they were wrong. Rather, because in the many witchcraft palavers I had attended in villages and urban townships there was never such unanimity. There, accusations were always contested. Moreover, they can come back with a vengeance on the one who started the alert. An accuser can easily become suspected for being "like the owl who calls the witches for their meetings in the night." There is no danger for this among the movie watchers; they are at a safe distance, and there is no risk of becoming personally involved. Witchcraft-on-the-screen is at a safe distance and offers comfortable confirmation. Radical distinctions seem to fix a fluid and always contested form of knowledge.

\section{Lessons to be learned?}

All over the world, the new social media seem to have intensified a fragmentation of reality that has been part and parcel of daily life in Africa for as long as we can go back. This does not preclude that African history as well has been marked by constant efforts to reach unification of meaning and control over what could count as knowledge. Yet, to Africans, the idea of "alternative facts," "fake news," and "multiple realities" is certainly not new. Which inevitably leads to the question, to what extent the experiences of people in Africa offer certain lessons for the disarray besetting publics in the West, now that the full implications of the social media revolution (unbridled streams of "news" and "information") have made themselves felt.

There was, indeed, an obvious answer in what my Maka friends taught me, centered around the word bouima, which is always translated as blinder - a common word in Francophone Africa. To Anglophone readers, it may sound as an obvious response to éblouissement that could be translated as "blinding,"

but the link is less direct. Blinder is used in the sense of "armoring." It is a vital notion in the therapies that nganga, the healers quoted before, are supposed 
to offer to their clients; they have to armor the client against evil attacks. There are many ways to do this: by midu ("medicine" = charged objects), by bathing the client in special concoctions, or by herbal preparations, among other methods. Interestingly, all these forms of "armoring" will only work if the client follows the itsi (interdictions). The nganga will affirm the working of the armoring by imposing a series of interdictions, and many are the stories of clients who came to grief despite the nganga's protections because they did not respect the interdictions.

Again, this not unique to Africa. In Favret Saada's book on witchcraft in Normandy, quoted before (1977), the healers (désorcelleurs) are supposed to work similarly through "closing off" the farm by placing magical barriers, refusing any physical contact with the suspected attacker, blocking him by scattering salt, and so forth. The result forces the evil that is directed against the client's farm to fly back against the attacker. Thus, the client's farm will regain its prosperity, while the attacker's farm withers away. All this is strongly reminiscent of the basic phrase used by so many African healers: renvoyer le mal (sending back the evil), as the basic thing they do. Yet, is such blinder relevant for global disarray over fake news, trolls, and alternative facts? It seems to parallel recent attempts of the U.S. Congress to discipline Facebook, or all the efforts globally to block Russians trolls, and so on. One can wonder about their effectiveness. My earlier quote from Mbembe (2016a) on "the unconscious now roaming free" and the new media as "the new infrastructures of the unconscious" is relevant here. Any attempt to block the internet might be as precarious as the nganga's efforts to "armor" their clients against the witches.

However, nganga do more than just blinder. They are only able to do this since they have acquired a new, visionary capacity: the "second pair of eyes." We can also compare the nganga's powers to what psychoanalysts claim to be able to do. Before building up the patients' new certainties, their existing defenses have to be destroyed; the patient has to open up by a "confession" and face the sources of aggression (s)he refuses to see. Only after such opening up, can (s)he be reconstructed. The emphasis in many witchcraft imaginaries about acquiring a "second pair of eyes" seems to parallel such an idea of opening up as the first need. It can be compared also to the extra vistas provided by the internet (which for so many people seem now to replace conversation and exchange in the most direct way). Eric de Rosny, the Jesuit priest quoted before, who wrote such a beautiful book (1981) about his initiation as a nganga by his "professor" in Douala, described to me the moment when his eyes were "opened" as a dreadful moment-a sensation of being surrounded by such omnipresent violence that only his Jesuit training enabled him to endure it. Afterward, he became a widely respected healer, even having his own show on the radio where he used his second sight to help people in a very practical sense. Clearly, it is possible to control the violence of the second sight. It might be worthwhile to further reflect on the relevance of this to people's struggles in other parts of the world, trying to 
cope with the torrents of information let loose by the internet that sometimes seem to sweep us off our feet.

The great accomplishment of Achille Mbembe's Abiola lecture is that he succeeded in evoking a visionary framework - almost "dazzling" —in which such a "pluriversity" of various forms of knowledge is becoming not only possible, but also extremely urgent.

\section{References}

Belinga, Eno S. M., and Jane Guyer. 1995."Wealth in People and Wealth in Knowledge: Accumulation and Composition in Equatorial Africa." Journal of African History 36 (1).

Buyandelger, Manduhai. 2013. Tragic Spirits: Shamanism, Memory and Gender in Contemporary Mongolia. Chicago: University of Chicago Press.

Comaroff, Jean, and John Comaroff. 2012. Theories from the South-Or, How EuroAmerica is Evolving Toward Africa. London: Routledge.

De Rosny, Eric. 1981. Les yeux de ma chèure—Sur les pas des maîtres de la nuit en pays douala. Paris: Plon. (English translation, 2004: Healers in the Night. Eugene, Oregon: Wipf and Stock.)

Douglas, Mary. 1970/1996. Natural Symbols. London: Routledge.

Favret Saada, Jeanne. 1977. Les mots, la mort et les sorts. Paris: Gallimard. (English translation, 1980: Deadly Words: Witchcraft in the Bocage. Cambridge: Cambridge University Press.)

Geschiere, Peter. 1999. "Globalization and the Power of Indeterminate Meaning: Witchcraft and Spirit Cults in Africa and East Asia." In Globalization and IdentityDialectics of Flow and Closure, edited by B. Meyer \& P. Geschiere, 211-38. Oxford: Blackwell.

- 2007. "Regional Shifts: Marginal Gains and Ethnic Stereotypes." African Studies Review 50 (2): 43-56.

- 2013. Witchcraft, Intimacy and Trust-Africa in Comparison. Chicago: University of Chicago Press.

- 2016. "Witchcraft, Shamanism and Nostalgia-A Review Essay." Comparative Studies in Society and History 58 (1): 242-65.

—. 2017. "A 'Vortex of Identities': Freemasonry, Witchcraft, and Postcolonial Homophobia." African Studies Review 60 (2): 7-35.

Guyer, Jane. 1993. "Wealth in People and Self-Realization in Equatorial Africa." Man (n.s.) 28 (2): 343-65.

- 1996. "Traditions of Invention in Equatorial Africa." African Studies Review 39 (3): 1-29.

- 2004. Marginal Gains: Monetary Transactions in Atlantic Africa. Chicago: University of Chicago Press.

Larkin, Brian. 2008. Signal and Noise: Media, Infrastructure, and Urban Culture in Nigeria. Durham, North Carolina: Duke University Press.

Lattas, Andrew. 2010. Dreams, Madness, and Fairy Tales in New Britain. Durham, North Carolina: Carolina Academic Press.

Mbembe, Achille. 2016a. "The Age of Humanism is Ending." Mail and Guardian, December 12.

—. 2016b. "Future Knowledges." The Abiola Lecture, Annual Conference of the African Studies Association, Washington. 
Meyer, Birgit. 2015. Sensational Movies_Video, Vision and Christianity in Ghana. Berkeley: University of California Press.

Nyamnjoh, Francis. 2017. "Incompleteness and Conviviality: A Reflection on International Research Collaboration from an African Perspective." In African Virtues in the Pursuit of Convivality: Exploring Local Solutions in Light of Global Perspectives, edited by Y. Gebre, I. Ohta, and M. Matsuda, 339-77. Bamenda: Langaa / Kyoto: CAAS.

Pedersen, Morton. 2011. Not Quite Shamans—Spirit Worlds and Political Lives in Northern Mongolia. Ithaca: Cornell Press.

Rio, Knut, M. McCarthy, and R. Blanes, eds. 2017. Pentecostalism and WitchcraftSpiritual Warfare in Africa and Melanesia. London: Palgrave Macmillan.

Taussig, Michael. 1987. Shamanism, Colonialism and the Wild Man: A Study of Terror and Healing. Chicago: University of Chicago Press.

Tonda, Joseph. 2002. La guérison divine en Afrique centrale (Congo, Gabon). Paris: Karthala.

- 2005. Le souverain moderne. Paris: Karthala.

. 2015. L’impérialisme postcolonial_Critique de la société des éblouissements. Paris: Karthala.

Viveiros de Castro, Eduardo. 2009. Métaphysiques cannibales: Lignes d'anthropologie structurale. Paris: Presses Universitaires de France.

Weller, Robert P. 1994. Resistance, Chaos and Control in China. London: Macmillan. Warnier, Jean-Pierre. 2007. The Pot-King — The Body and Technologies of Power. Leiden: Brill.

\section{Notes}

1. Unfortunately, Karthala publishing house decided that his book had to be published under the title L'impérialisme colonial, but it is clearly this notion of éblouissement-which now appears only in the subtitle-that is at the core of Tonda's message. See also Tonda 2002 and 2005.

2. See Francis Nyamnjoh's recent explorations around the theme of "incompleteness" as an ontological aspect of human being (for him, not only in Africa but everywhere. Nyamnjoh 2017).

3. At the University of Natal in Pieter Maritzburg, students did set fire to the library; there were smaller incidents of arson at the University of Cape Town.

4. Of course, this contrast does not imply that Mbembe denies the urgency of decolonizing the university. However, he distances himself from decolonizing under the sign of "difference" and "separation." The solution he proposes in his Abiola lecture is rather to create space for a plurality of forms of knowledge (a "pluriversalist" approach) that can inspire each other, without any idea of inequality or hierarchy (Mbembe 2016b:8).

5. Mbembe seems to refer here to users' experience of the internet as liberating. Of course, he is keenly aware of new controlling elements-algorithms, etc.that are all the more effective since they remain hidden.

6. See Jean and John Comaroff in Theories from the South (2012).

7. See also Sasha Newell's seminal analysis elsewhere in this issue of the spectacular articulations between the "virtual" and the "second" world (internet and witchcraft) that have recently developed in the world of the brouteurs in Ivory Coast. Especially important is Newell's insistence on the mystical allure of the internet. 
Additionally, see Pype (also in this volume) on "connectivity" as crucial especially in young Africans' obsession with new technology; of course "to be connected" is basic in witchcraft imaginaries as well.

8. See Geschiere 2013 and 2016 for the complex articulation between witchcraft and kinship.

9. See Eric de Rosny (1981) in his fascinating book on his initiation by a "professor" in Douala to whom, at the supreme moment, he had to give "a hairless animal" (= a human being). 